P524

\title{
Forward Model of the Eocene-Miocene Orogenic Evolution of Polish and Slovak Outer Carpathians
}

L. Gagala* (Institute of Earth Sciences 'Jaume Almera'), J. Vergés (Institute of Earth Sciences 'Jaume Almera'), E. Saura (Institute of Earth Sciences 'Jaume Almera'), T. Malata (Polish Geological Institute), J.C. Ringenbach (Total E\&P), P. Werner (Total) \& P. Krzywiec (Polish Geological Institute)

\section{SUMMARY}

The Polish and Slovak Outer Carpathians are the Eocene-Miocene accretionary wedge resting upon flexed margin of the European Plate. Forward modeling has shown that the its kinematics was controlled not only by frontal accretion on new thrust sheets but also by thickening of its internal parts driven by out-ofsequence thrusting. Growth and arrival of the accretionary wedge to its present position resulted from at least $495 \mathrm{~km}$ of orogenic convergence. Rates of convergence were evolving from $10.5 \mathrm{~mm} / \mathrm{y}$ between 35.2 and $25.0 \mathrm{Ma}$ to $24.2 \mathrm{~mm} / \mathrm{y}$ from $25.0 \mathrm{Ma}$ onwards. This acceleration may be attributed to the onset of rollback of the lower plate. 


\section{Introduction}

The Carpathians are an orogenic belt shaped by the closure of Tethys Ocean during the convergence between European and African plates (Csontos and Vörös 2004, Golonka et al. 2006, Schmid et al. 2008). It is divided in two domains: the Inner and Outer Carpathians (IC and OC, respectively). The IC were shaped during early stages of collision (Csontos and Vörös 2004) while the OC evolved as an accretionary wedge during the final advance of the IC against the margin of the European Plate (Ustaszewski et al. 2008).

Below we show a 2D kinematic model of the late Eocene-middle Miocene evolution of the OC built upon a balanced section crossing the borderland of Poland and Slovakia (Fig. 1). The model illustrates the internal kinematics of the OC accretionary wedge and evolution of the wedge-foreland system as a whole.

The structure of the OC and pre-orogenic geometry of sedimentary basins have been revealed by standard techniques of section balancing and restoration, integrating all available data (structural, stratigraphic and seismic). Then the restored section was used as a starting point for the kinematic model. Successive steps of the model are primarily constrained by geometry of the balanced section and are in agreement with geological data defining the evolution of the OC foreland basin.

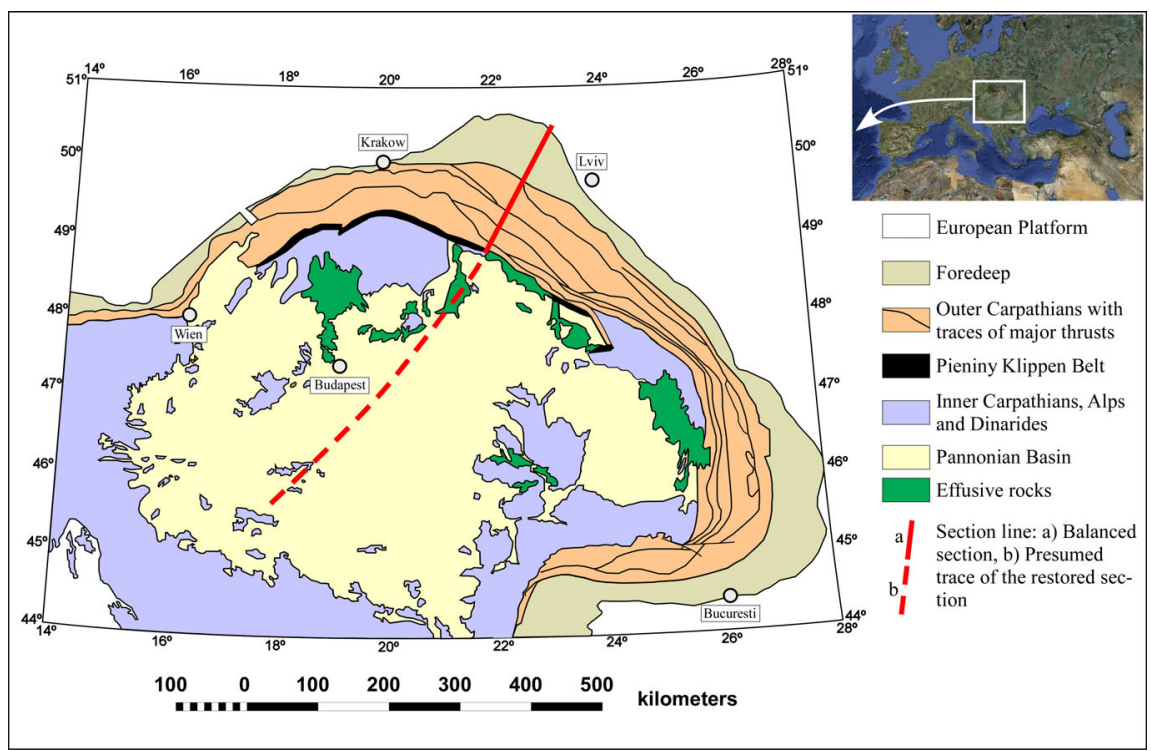

Figure 1 General geological map of the Carpathians with traces of balanced and restored sections (after Picha 1996, simplifed). The trace of restored section defines a path of the kinematic model.

\section{Structure}

Two main domains are distinguished in the structure of the $\mathrm{OC}$ in the section area: thrust and fold belt and foredeep (Fig. 2). The thrust and fold belt displays a geometry of an imbricate fan, complicated by major thrusts carrying groups of thrust sheets one on top another. These faults separate structural units originated by deformation of individual subbasins. From $\mathrm{N}$ to $\mathrm{S}$ these are Stebnik, Skole, Silesian, Dukla and Magura units.

\section{Kinematic model}

The total shortening applied for the model is $495 \mathrm{~km}(79 \%)$. Here we describe only the selected steps (Fig. 3). (a) Initial stage derived from section restoration. (b) Mostly frontal accretion of Magura thrust sheets with minor out-of-sequence thickening of the rear portion of the wedge. (c) Major out-of sequence thickening of the Magura wedge and relative stagnation of the deformation front. (d) Off-scrapping of the basement slices from the Marmarosh Ridge followed by a frontal accretion of Dukla thrust sheets. (e) Arrival of the deformation front to the 


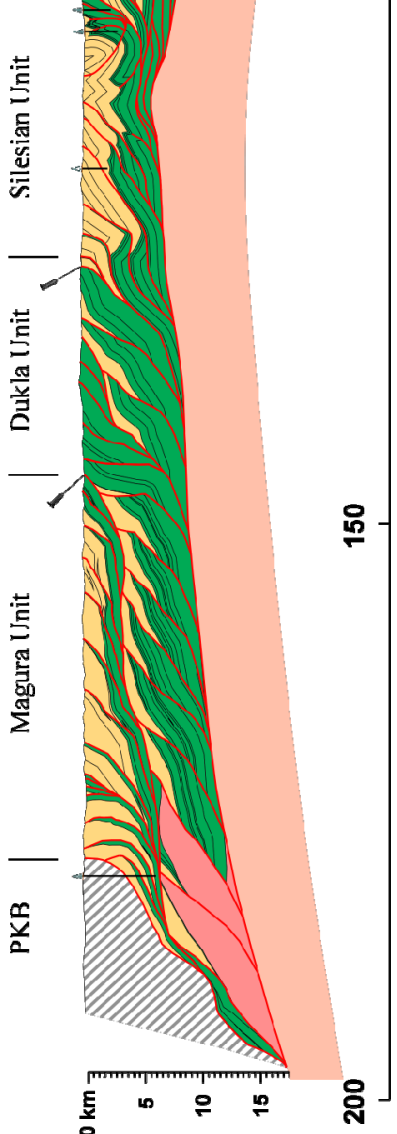

drowned Silesian Ridge and frontal imbrication of its synorogenic cover. (f) Main phase of wedge thickening by emplacement of older part of the wedge (Magura Unit) on top of Dukla Unit as well as internal scooping of the Dukla Unit itself. Long stagnation of deformation front. (g) Mostly frontal accretion of thrust sheets from Silesian and Skole subbasins coeval with minor out-of-sequence thrusting at the contact of Dukla and Silesian Units. (h) Emplacement of the wedge on top of European Plate and imbrication of the internal foredeep associated with minor out-of-sequence readjustments at the junction of Silesian and Skole Units. (i) Final arrival of the wedge to its present-day position with activation of basement and deformation of the wedge as a whole. Sinistral displacements between the OC and their backstop.

Integration of geometries, kinematics and sedimentation into a single model offered us a possibility for tracing evolution of a convergence rate. In the period corresponding to an imbrication of the Magura basin between 35.3 and 25.0 it oscillated around $10.5 \mathrm{~mm} / \mathrm{y}$. Since $25.0 \mathrm{Ma}$ it increased to $24.2 \mathrm{~mm} / \mathrm{y}$ and remained high almost until the end of orogenic history at $10.5 \mathrm{Ma}$.

\section{Discussion and conclusions}

The total shortening of $495 \mathrm{~km}$ is higher than previously estimated (Nemčok et al. 2006, Roca et al. 1995, Roure et al. 1993). It results from the application of thinner thrust sheets. However, we believe that this number is still the minimum value.

The model shows that the growth of the OC wedge cannot be explained by a uniform, in-sequence nucleation of successive thrusts since the resultant intermediate geometries do not fit with existing stratigraphic and sedimentological data. Depending on the amount of applied flexural subsidence either a higher topography of the wedge or greater depths of the foreland basins were produced than supported by geological evidence (Malata and Poprawa 2006, Oszczypko and Oszczypko-Clowes 2006, Słomka et al. 2006). The solution of this problem is an out-ofsequence reactivation of some of the thrusts resulting in acceptable geometries of the model. The most important of out-of-sequence events was the emplacement of Magura Unit on top of Dukla imbricates between 22.8 and $17.8 \mathrm{Ma}$ (Fig. 3f), evidenced by coeval decrease in sedimentation rate in the distal foreland, marking a stagnation of the deformation front and final cessation of wedge-top deposition on the Magura Unit.

Figure 2 Balanced cross section through the Polish and Slovak Outer Carpathians. 

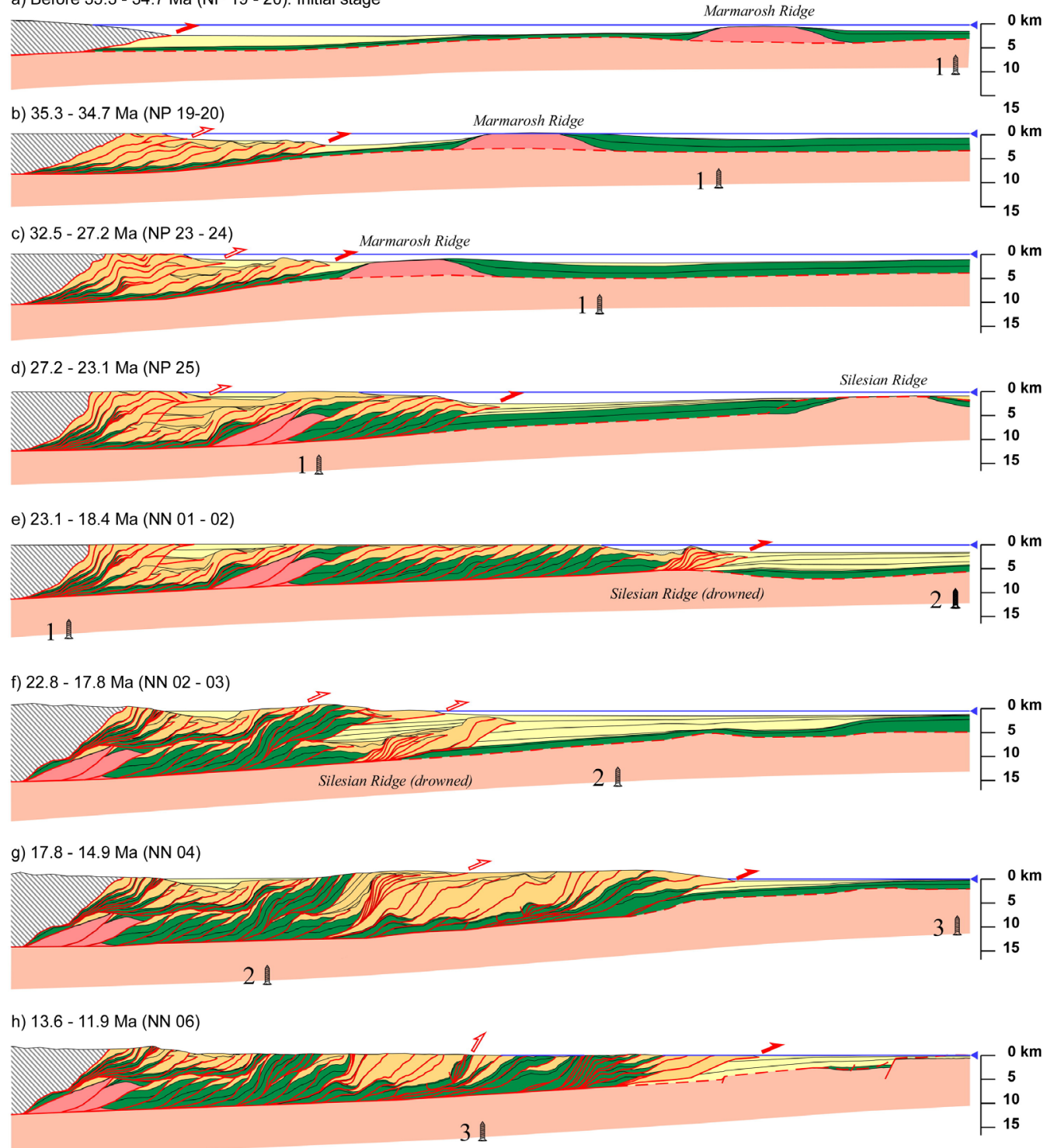

i) After 11.0 - 10.5 Ma (NN 08). Top - final geometry of the model. Bottom - balanced section.

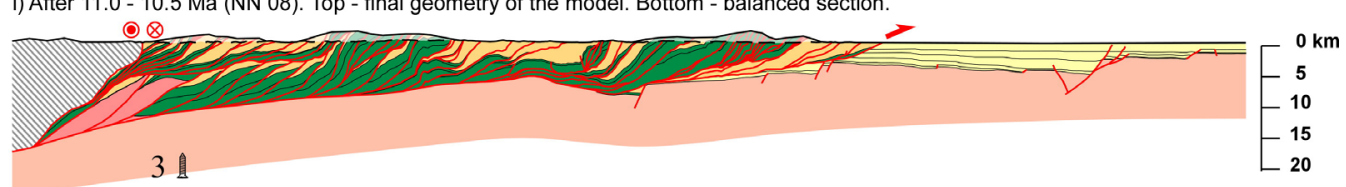

31

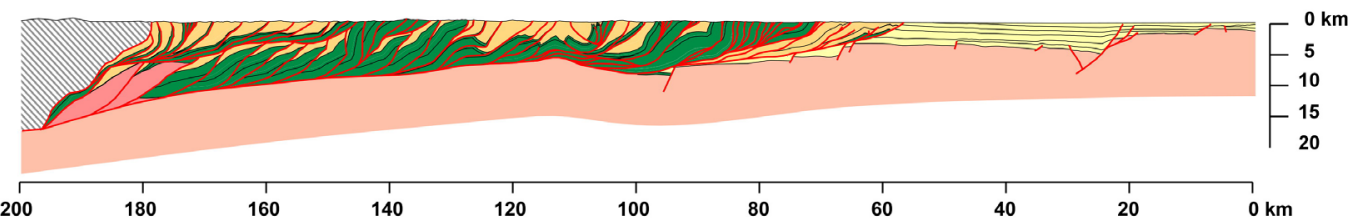

Pre-orogenic series

\begin{tabular}{|l|l|l|l}
\hline $\mathrm{a}$ & $\mathrm{b}$ & Syn-orogenic series: a) Deformed b) Not deformed
\end{tabular}

\begin{tabular}{|l|l|l|l}
\hline $\mathrm{a}$ & $\mathrm{b}$ \\
\hline
\end{tabular}

IIIII Low-relief backstop (Inner Carpathians)

Model error: Difference between corresponding structural lev-

els of the balanced section and the model; refers to step i)

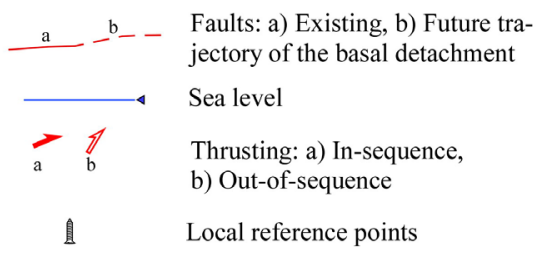

Figure 3 (previous page). Selected stages of the kinematic model. Its final geometry is compared with the balanced section. Only minor differences testify for its kinematic admissibility. 
The geological significance of an inferred increase in the convergence rate at $25 \mathrm{Ma}$ is a challenge. In relation to previous works we may state, that it fits well with the hypothesis of the slab roll-back as the driving mechanism of subduction (Nemčok et al. 2006, Nemčok et al. 1998, Royden 1993). The interval around 25 Ma may potentially correspond to the onset of this process, resulting in an acceleration of convergence. This reasoning may also help to explain why basement slices of the Marmarosh Ridge were incorporated into the structure of the accretionary wedge, while the Silesian Ridge entirely remained in the footwall. According to the kinematic model the Marmarosh Ridge was overridden by the wedge before $25 \mathrm{Ma}$ (Fig $3 \mathrm{c}, \mathrm{d}$ ) thus before the proposed slab roll-back and the Silesian Ridge not earlier than $23.1 \mathrm{Ma}$ (Fig. 3 e, f) already after initiation of this process.

\section{Acknowledgments}

The research has been inspired and supported by TOTAL ${ }^{\circledR}$. We are grateful for donation of data and permission to publish the results.

\section{References}

Csontos, L. and Vörös, A. [2004] Mesozoic plate tectonic reconstruction of the Carpathian region. Palaeogeography, Palaeoclimatology, Palaeoecology 210(1), 1-56.

Golonka, J., Gahagan, L., Krobicki, K., Marko, F., Oszczypko, N. and Ślączka, A. [2006] Plate-tectonic Evolution and Paleogeography of the Circum-Carpathian Region. In: Golonka, J. and Picha, F. J. (Eds.) The Carpathians and their foreland: Geology and hydrocarbon resources. AAPG Memoir, 84. The American Association of Petroleum Geologists, Tulsa, Oklahoma, U.S.A., 11-46.

Malata, T. and Poprawa, P. [2006] Evolution of the Dukla Basin (In Polish with English summary). In: Oszczypko, N., Uchman, A. and Malata, E. (Eds.) Palaeotectonic Evolution of the Outer Carpathian and Pieniny Klippen Belt Basins. Institute of Earth Sciences, Jagiellonian University, Kraków, 127-133.

Nemčok, M., Krzywiec, P., Wojtaszek, M., Ludhová, L., Klecker, R. A., Sercombe, W. J. and Coward, M. P. [2006] Tertiary development of the Polish and eastern Slovak parts of the Carpathian accretionary wedge: insights from balanced cross sections. Geologica Carpathica 57(5), 355-370.

Nemčok, M., Pospíšil, L., Hrušecký, I. and Zsíros, T. [2006] Subduction in the remnant Carpathian Flysch Basin. In: Golonka, J. and Picha, F. J. (Eds.) The Carpathians and their foreland: Geology and hydrocarbon resources. AAPG Memoir, The American Association of Petroleum Geologists, Tulsa, Oklahoma, USA,

Nemčok, M., Pospíšil, L., Lexa, J. and Donelick, R. A. [1998] Tertiary subduction and slab break-off model of the Carpathian-Pannonian region. Tectonophysics 295(3-4), 307-340.

Oszczypko, N. and Oszczypko-Clowes, M. [2006] Evolution of the Magura Basin (In Polish with English summary). In: Oszczypko, N., Uchman, A. and Malata, E. (Eds.) Palaeotectonic Evolution of the Outer Carpathian and Pieniny Klippen Belt Basins. Institute of Geological Sciences, Jagiellonian University, Kraków, 133-164.

Picha, F. J. [1996] Exloring for hydrocarbons under thrust belts: a challenging new frontier in the Carpathians and elsewhere. AAPG Bulletin 89, 1547-1564.

Roca, E., Bessereau, G., Jawor, E., Kotarba, M. and Roure, F. [1995] Pre-Neogene evolution of the Western Carpathians: Contstraints from the Bochnia-Tatra Mountains section (Polish Western Carpathians). Tectonics 14(4), 855-873.

Roure, F., Roca, E. and Sassi, W. [1993] The Neogene evolution of the outer Carpathian flysch units (Poland, Ukraine and Romania): kinematics of a foreland/fold-and-thrust belt system. Sedimentary Geology 86(1-2), 177-201. Royden, L. H. [1993] Evolution of retreating subduction boundaries formed during continental collision. Tectonics 12(3), 629-638.

Schmid, S. M., Bernoulli, D., Fügenschuh, B., Matenco, L., Schefer, S., Schuster, R., Tischler, M. and Ustaszewski, K. [2008] The Alpine-Carpathian-Dinaridic orogenic system: correlation and evolution of tectonic units. Swiss Journal of Geosciences 101(1), 139-183.

Słomka, T., Malata, T., Leśniak, T., Oszczypko, N. and Poprawa, P. [2006] Evolution of the Silesian and Subsilesian basins. (In Polish with English summary). In: Oszczypko, N., Uchman, A. and Malata, E. (Eds.) Palaeotectonic Evolution of the Outer Carpathian and Pieniny Klippen Belt Basins. Institute of Geological Sciences, Jagiellonian University, Kraków, 111-126.

Ustaszewski, K., Schmid, S. M., Fügenschuh, B., Tischler, M., Kissling, E. and Spakman, W. [2008] A map-view restoration of the Alpine-Carpathian-Dinaridic system the Early Miocene. Swiss Journal of Geosciences 101(Supplement 1), S273-S294. 